\title{
Nursing Students' Simulation Training Experience: A Qualitative Study
}

\author{
Hemşirelik Öğrencilerinin Simülasyon Eğitimi Deneyimi: Nitel Bir Çalışma
}

Sema KOÇAN ${ }^{1}$, Özlem ALBAYRAK ${ }^{2}$

\begin{abstract}
The aim of the study is to determine the experiences of nursing students in simulation education. The universe of the research consists of the students attending the operating room nursing course in the nursing department. The entire universe was included in the study $(n=15)$. Each student experienced the simulation training twice with three weeks apart. Qualitative data, on the other hand, were obtained with a semi-structured interview form after the simulation training was completed and were analyzed using the "phenomenological analysis" method. Three main themes were determined in the research: "our breaking point in professional awareness", "looking in the mirror of our professional skills", "contributions of simulation training". Most students stated that the simulation was instructive and increased their self-confidence. Some of the students stated that they developed a sense of responsibility, that simulation training increased professional awareness, and that it was a breaking point. Others stated that it is meaningful to monitor their progress in the debriefing rooms and that the evaluations show how they are in terms of professional practices. The results show that simulation applications that create realistic clinical situations and enable students to practice in a safe environment support nursing students and create a positive perception. It is recommended to integrate simulation applications into the nursing education curriculum.
\end{abstract}

Keywords: Experience, Nursing, Qualitative Research, Simulation Training

\section{ÖZ}

Araştırmanın amacı hemşirelik öğrencilerinin simülasyon eğitimine ilişkin deneyimlerini belirlemektir. Araştırmanın evrenini hemşirelik bölümünde ameliyathane hemşireliği dersine devam eden öğrenciler oluşturmaktadır. Araştırmaya evrenin tamamı alındı $(n=15)$. Üçer hafta arayla her bir öğrenci simülasyon eğitimlerini iki kez deneyimledi. Nitel veriler simülasyon eğitimleri tamamlandıktan sonra yarı yapılandırılmış görüşme formu ile elde edildi ve "fenomenolojik analiz" yöntemi ile analiz edildi. Araştırmada üç ana tema belirlendi: "mesleki farkındalıkta kırılma noktamı", "mesleki becerilerimize aynadan bakmak" ve "simülasyon eğitiminin katkıları". Öğrencilerin çoğu simülasyonun öğretici olduğunu ve özgüvenlerini artırdığını belirtti. Öğrencilerin bazıları sorumluluk duygusunu geliştirdiğini, simülasyon eğitiminin mesleki farkındalığı artırdı ğını, bir kırılma noktası olduğunu ifade etti. Bazıları ise, çözümleme odalarında kendilerindeki ilerlemeleri izlemenin anlam verici olduğunu, değerlendirmelerin mesleki uygulamalar açısından ne durumda olduklarını gösterdiğini belirttiler. Elde edilen sonuçlar, gerçekçi klinik durumları oluşturan ve öğrencilere güvenli bir ortamda uygulama yapmalarını sağlayan simülasyon uygulamalarının hemşirelik öğrencilerini desteklediğini ve olumlu alg1 oluşturduğunu göstermektedir. Hemşirelik eğitimi müfredatına simülasyon uygulamalarının entegre edilmesi önerilmektedir.

Anahtar Kelimeler: Deneyim, Hemşirelik, Nitel Çalışma, Simülasyon Eğitimi

This study was carried out in acoordence with the rules of research and publication ethics. Ethical statement This is a cross-sectional study of all procedures conformed to the tenets of the Declaration of Helsinki, and the study was approved by the Recep Tayyip Erdogan University of Medicine Scientific Research Ethics Committee (Confirm number: 40465587-26) and institution permit. This study was previously presented as an oral presentation at 3rd International \& 11th National Turkish Surgical and Operating Room Nursing Congress, October 3-6, 2019, Izmir, Türkiye.

${ }^{1}$ Dr. Öğr. Üyesi, SEMA KOÇAN, Cerrahi Hastalıkları Hemşireliği, Recep Tayyip Erdoğan Üniversitesi Sağlık Bilimleri Fakültesi, semakocan66@gmail.com, ORCID: https://orcid.org/0000-0002-9049-3798

${ }^{2}$ Öğr. Gör., ÖZLEM ALBAYRAK, Hemşirelik Esasları, Recep Tayyip Erdoğan Üniversitesi Sağlık Bilimleri Fakültesi, ozlem.albayrak@erdogan.edu.tr, ORCID: https://orcid.org/0000-0002-9167-307X

İletişim / Corresponding Author: $\quad$ Sema KOÇAN $\quad$ Geliş Tarihi / Received: 21.07.2021

e-posta/e-mail: $\quad$ semakocan66@gmail.com $\quad$ Kabul Tarihi/Accepted: 31.10.2021 


\section{INTRODUCTION}

Nursing is a profession that requires a combination of theoretical knowledge and practical skills. Nursing education aims to teach values, knowledge, ethics, and skills related to the profession and ways to transform these into behaviors. ${ }^{1}$ Various educational tools are used to improve and strengthen the knowledge and skills of students.

Students are unable to acquire sufficient clinical experience due to shorter hospitalization times, less time spent in clinics, and limited areas of application. ${ }^{2}$ Nevertheless, nurses are still required to perform their professional tasks with clinical expertise upon completing their professional education. Considering these limitations, simulation-based learning appears to augment the theoretical knowledge and professional skills of nursing students. ${ }^{3}$

Simulation defines a technique or tool attempting to create reality or a real-like environment. ${ }^{4}$ In other words, simulation is a method in which a real-like model about an incident or situation is developed and repeated. ${ }^{5}$ Simulation in nursing education depicts incidents or situations similar to those that students would encounter in hospitals. ${ }^{6}$ Furthermore, incidents or situations which students cannot observe in a laboratory or classroom environment are demonstrated in simulations. $^{5}$

The use of simulation provides the opportunity of experience-based learning, increases nursing students' self- confidence, and develops their decision-making skills. In addition, with simulation training, students overcome the fear of misunderstanding the patient's situation and the fear of failure, and gain skills in a safe environment with the best simulation. 7-10 Other benefits of simulation training show that students' anxieties decrease, and their performance and the quality of the tasks they perform increase with the repetition in simulation training. $6,11,12$ Simulation training allows students to acquire experience without endangering patients by observing their mistakes and processing the feedback they receive after simulations. ${ }^{9,13,14}$

In conclusion, since nursing requires cognitive, affective, and psychomotor skills, students should be provided opportunities to develop these traits. Simulation helps students improve their professional skills and clinical competencies in a realistic patient care environment. For this reason, it should be used to augment the nursing curriculum.

The study was planned to determine the experiences of a group of nursing students during simulation training.

\section{MATERIAL AND METHODS}

\section{Research Type}

This research was conducted using a phenomenological research design, one of the qualitative research methods.

\section{Aspect of the Research Ethics}

Permission to conduct the study was obtained from the Recep Tayyip Erdogan University of Medicine Scientific Research Ethics Committee (Confirm number: 40465587-26). Institutional permission was obtained from the Recep Tayyip Erdoğan health school in order to carry out the study with the students (Confirm number: 98295262-900-E.844). Furthermore, the study was conducted with the informed consent of each student. The students were informed about the aim of the study, video recording of the simulation training, and sound recording of the interviews for the qualitative data. Verbal consent was taken from the students with audio recording in addition to the written consent.

\section{Research Sample}

In the research, it was aimed to reach the entire universe. All of the students were 
included in the study. The research sample consisted of 15 nursing students who were continuing an operating room nursing course in the department of nursing at a university's school of health. They also had studied the internal diseases and surgical diseases nursing course, participated in simulation training, and voluntarily participated in the research. The research was conducted between November-December 2018. Each student participated in the simulation training twice with an interval of three weeks.

\section{Simulation Training Features}

Before the simulation training, a scenario about greeting and monitoring a patient after the surgery who mastectomy of the left breast only was created. Before the first simulation training, reminder texts that summarize the subject (Aims of post-operative nursing care, post-operative care of Modified Radical Mastectomy (MRM) patient, and fundamentals of medication preparation and application) were sent via the software system.

The medium fidelity simulator was used in the scenario and the simulator was prepared in accordance with the scenario. For this, the following procedures were applied to each student by both researchers before the simulation training:

- Two drains including artificial blood were placed under the left breast and left armpit of the simulator and closed with dressing.

- Urethral catheterization was performed and weak tea was poured into the urine drainage bag to resemble urine.

- The simulator was clothed with a surgical shirt and bonnet.

- The wristband was put on the simulator for patient identification.

- The simulator was placed on the sickbed and covered with a sheet.

While the materials that students may need (blanket for warming the patient, pillow for arm elevation, the patient file including doctor's treatment request form and nurse observation form for the registry and the monitoring of treatment) while performing the scenario was placed in the patient room, medications included in patient treatment (analgesic, antibiotic, antiemetic, and $500 \mathrm{ml}$ of fluid) and materials that would be used for treatment (injectors, serum sets, sharp object toolbox, plaster, sphygmomanometer, stethoscope, etc.) were left in the medication preparation room. The students were asked to greet the female patient who underwent MRM surgery. The simulation training was managed from the control room and the training was recorded using a special software program. Dubbing (sounds such as groaning and gagging or short sentences such as "I am cold", "I have a lot of pain") was performed by the first researcher for the simulator. Furthermore, the pulse, blood pressure, and respiration values of the patient were changed by the moderator from the computer panel in the control room before each training. After the training, the patient, patient room, and medication preparation room were restored.

\section{Data Collection Tools and Data Collection}

\section{Student Identification Form}

The questionnaire consists of four questions including the age, gender, employment status, and simulation experience status of students.

\section{Semi-Structured Interview Form}

The qualitative data were collected with a semi-structured questionnaire created by the researchers after completing the simulation training. The interviews were conducted as a focus group discussion. All the interviews were recorded with the approval of students with an audio recorder. Audio recordings are archived on the hard disk so that only the authors can access them. There are six questions in the interview form about the feelings and thoughts of students towards simulation training. The questions included in the semi-structured interview form are as follows:

- What did you feel before starting simulation training? 
- What did you feel during simulation training?

- What did you feel after the simulation training?

- What did you feel when you saw your applications in debriefing rooms?

- What do you think when you compare your first and second training?

- What can you say when you compare the theoretical and applied courses with the simulation training?

\section{Evaluation of Qualitative Data}

The phenomenological research approach was used in the qualitative study. In the collection of qualitative data was conducted focus group interviews. The students were separated into two groups for the interviews as 8 students in the first group and 7 students in the second group. The interview session was performed with a moderator in a classroom environment where a recording device and an oval seating arrangement was provided. The students were provided to wear number tags from one to eight and seating was arranged in accordance with their number tags. The students were informed about the research and audio recording. Both verbal and written consent was taken from the students about their voluntary participation. Open-ended questions that were priorly prepared by the researchers were asked by the moderator and the answers were recorded with an audio recorder. The sessions were finalized when the data started to repeat. Each group interview lasted approximately 55 minutes. The data obtained from the interviews were created by the two researchers. The phenomenological analysis method was used in the analysis of qualitative data. For this, the data included in the sound recording were completely written and analyzed by researchers. The first part of the analysis involved three readings. The purpose of the first reading was to remind researchers of the objectives of the study and the data obtained. In the second reading, similar words and sentences were determined and codes were created. The third reading facilitated the allocation of codes to existing or new categories. The researchers made comparisons to identify common and separate aspects of the data they obtained. Sample expressions were placed in the raw data pool to represent categories. Thematicization was made by grouping categories related to each other. Sometimes transcripts and recordings have been reviewed to make sure they are placed in the most appropriate theme. The manual analysis provided a clear view and understanding of all emerging themes. ${ }^{15,16}$

For ensure reliability in qualitative research;

- The researchers provided long-term interaction with the participants. Interviews with the participants lasted 55 minutes. The researchers were found in the environment where the study was conducted.

- A relationship based on mutual trust was established by being in the same environment. It also ensured that correct and complete answers were received.

- Participants were asked whether the study findings reflected their own thoughts correctly. Participants confirmation was made.

- The statements of the participants were included in the findings section without any change.

- All participants were treated similarly/consistently in the collection and analysis of the research data. The same interview form and the same tape recorder were used in the interviews. 


\section{RESULTS AND DISCUSSION}

The mean age of students was $20.8 \pm 1.01$ and $53.3 \%$ of the students were male $(n=8)$ and $46.7 \%$ of the students were female. The students did not experience any simulation training and were not working in an institution.

Three main themes were determined after the interviews with students (Figure 1).

- Our breaking point in professional awareness

- Looking in the mirror of our professional skills

- Contributions of simulation training

Figure 1. Main Themes

\section{- Our breaking point in professional awareness}

The use of simulation in nursing education increases the self-confidence of students and improves professional skills by providing the opportunity to learn by experience. Furthermore, students can understand the philosophy of nursing by acquiring a holistic care application skill in a safe environment with simulation training. It was found that some of the students saw the simulation training as a breaking point in professional development, increasing the sense of responsibility and professional awareness.

"It significantly increased our sense of responsibility. We thought that "Now, we have learned". (5 $5^{\text {th }}$ Student)

"To be honest, I acquired a sense of seriousness while performing my duty. I have received a "pull yourself together" message in 15 minutes and I was astounded. It was a breaking point for me. Taking this responsibility increased my professional awareness and I felt that I grew up". (1 $\mathbf{1}^{\text {st }}$ Student)

"...We experienced the practices by taking responsibility and I have performed what I should do not by memorizing but by performing. For instance, I started to act in a planned way and by acknowledging the purposes even for simple acts such as eating". (12 ${ }^{\text {th }}$ Student)

It was determined that the most of the students thought that the simulation application should be in education.

"With the simulation, we have integrated the theoretical knowledge with practice. Dealing with patients is not like solving equations. Making mistakes while solving equations may cause a wrong value for $x, y$ or $z$. However, a tiny mistake made by the health personnel may cost someone's life. I believe that simulation training should definitely be included in our profession". ( $6^{\text {th }}$ Student)

"I believe that it is an education method that everyone should experience. It indicates that we should not memorize the information but place it into our lives". ( $3^{\text {rd }}$ Student)

\section{- Looking in the mirror of our professional skills}

It is crucial to provide feedback to students in clinical applications which is an essential part of nursing education. Regular feedbacks during the applications provide information to students about their applications, performances, and successes. Video recordings used in simulation training provides the opportunity for students to watch and evaluate their applications. It was found that some of the students considered watching their practices in the debriefing rooms as meaningful. In addition, it was determined that the evaluations made in the 
debriefing rooms created the perception that some students showed their situation in terms of professional practices.

"...It was significant for us to observe our improvement with our eyes". ( $7^{\text {th }}$ Student)

"The simulation showed me whether I learned or not and my progress in professional education". (11 ${ }^{\text {th }}$ Student)

"First, I watched a nurse who was dull, anxious, and immobile. The second time, most of my deficiencies were eliminated and I knew what to do. I overcame my fears". ( $2^{\text {nd }}$ Student)

It was determined that watching the applications in the defibring rooms caused disappointment in the majority of the students, and the students questioned themselves because of their applications.

"Frankly, I did not want to watch myself for the first time. I could more or less estimate what I had done, I had not done, and how I had or had not done these tasks. The first one was a disappointment. Furthermore, these feelings did not disappear instantly, we were ashamed of ourselves for a couple of days. We questioned ourselves. We were reduced to bits" (laughing and others are nodding). (9 $\mathbf{9}^{\text {th }}$

\section{Student)}

\section{- Contributions of simulation training}

Clinical practices may cause anxiety and stress in students due to conditions such as lack of experience, fear of hurting the patient, and unknown or difficult fields of application. The experienced anxiety and stress negatively affect the application performance and success of students. With simulation, students do not fear to hurt the patient and the repeated applications increase the performance, success, and selfconfidence of students. It was determined that most of the students described the simulation as instructive and stated that the simulation increased their self-confidence.

"It increases self-confidence and teaches us what to do for what purpose. It provides us to become aware of what we are". (14 ${ }^{\text {th }}$ Student)

"I felt down-to-earth. Before, I was looking for someone to trust even for the smallest duty that I could not perform. I was seeking help from my friends and nurses. However, now I push myself to the limit until I understand I cannot handle". (15 ${ }^{\text {th }}$ Student)

"I believe simulation prepares us for the profession. We have learned a lot in a very short period". ( $4^{\text {th }}$ Student)

The use of simulation in nursing education supports the development of students' professional skills and provides them to acquire sufficiency in terms of health care. Animated sample case presentations can be performed in a real clinical environment with the use of simulation and experience-based active learning opportunities can be provided to students. Furthermore, students learn both the information and professional skills integrated with the use of simulation.

The study was planned to determine the experiences of a group of nursing students during simulation training. In this part, qualitative findings of the experiences of students towards this training were discussed. In the conducted interviews, it was found that some of the students saw the simulation training as a breaking point in professional development, increasing the sense of responsibility and professional awareness.

Taking care of a patient without the supervision and feeling of reliance on a nurse in a real-like animated environment improved the students' sense of responsibility and increased the professional awareness of students. In the Report of Simulation in Nursing and Midwifery Training of the World Health Organization (2018), it was emphasized that the use of simulation in 
nursing and midwifery training increases the professional responsibilities. ${ }^{17}$

Giving feedback to students provides the opportunity to support positive behaviors, correct negative behaviors, and the efficiency of training. ${ }^{18,19}$ However, it should be paid attention to give feedback at the right time, in a certain subject, clear, and objective. In the study conducted by Günüşen and Üstün, students stated that the given feedbacks were overall and were given at the end of the clinical application. ${ }^{20}$ Whereas the feedback should be given during the application and should be clear and concrete. In the evaluation conducted after the simulation training, students observed their applications concretely with video recordings and the feedback was given to students right after the application with specific suggestions. It was found that some of the students considered watching their practices in the debriefing rooms as meaningful. In addition, it was determined that the evaluations made in the debriefing rooms created the perception that some students showed their situation in terms of professional practices.
Clinical applications that provide students to learn professional information and improve psychomotor skills may cause stress in students. This stress may be related to thoughts such as wrong applications, the fear of harming the patient, and encountering negative reactions of the patients or health personnel. ${ }^{21}$ This situation may cause social isolation, anxiety, incompliance, ineffective learning, low performance, and lack of selfconfidence in students. Students do not experience these negativities with the use of simulation, learn more permanently with repeated applications, and both their performance and self-confidence increase. It was determined that most of the students described the simulation as instructive and stated that the simulation increased their selfconfidence. In the study conducted by McRae et al. (2017) to determine the effect of cardiac resuscitation simulation on the self-confidence of nurses, a statistically significant increase was determined in the self-confidence scores of participants after the training. ${ }^{22}$

\section{CONCLUSION AND RECOMMENDATIONS}

In conclusion, the use of simulation in nursing education contributes to the learning experiences students. In the simulation, students can improve their professional skills in a real clinical environment integrated with realistic scenarios. It is suggested to use and popularize simulation as an education method in nursing education since it contributes to students, to concentrate on other real-like simulation methods apart from standard patient case discussion, and roleplay in addition to the use of models in nursing education institutions where a simulation laboratory does not exist until a proper simulation laboratory is established, and to make students feel that simulation training is significant for all the applied courses in the nursing curriculum and to apply the training. 


\section{REFERENCES}

1. Boztepe, H. ve Terzioğlu, F. (2013). "Hemşirelik Eğitiminde Beceri Değerlendirme”. Anadolu Hemşirelik ve Sağlık Bilimleri Dergisi, 16 (1), 57-63.

2. Jamshidi, N, Molazem, Z, Sharif, F, Torabizadeh, C. and Kalyani, M.N. (2016). "The Challenges of Nursing Students in the Clinical Learning Environment: A Qualitative Study". Scientific World Journal, 1, 1-7.

3. Norman, J. (2012). "Systematic Review of the Literature on Simulation in Nursing Education". Abnf Journal, 23 (2), 24-29.

4. Terzioğlu, F, Kapucu, S, Özdemir, L, Boztope, H, Duygulu, S, Tuna, Z. ve Akdemir, N. (2012) "Simülasyon Yöntemine İlișkin Hemşirelik Öğrencilerinin Görüşleri”. Sağlık Bilimleri Fakültesi Hemşirelik Dergisi, 16-23.

5. Edeer, A.D, ve Sarıkaya, A. (2015). "Hemşirelik Eğitiminde Simülasyon Kullanımı ve Simülasyon Tipleri”. Hemşirelikte Eğitim ve Araştırma Dergisi, 12 (2), 121-125.

6. Göriș, S, Bilgi, N, ve Bayindir, S.K. (2014). "Hemșirelik Eğitiminde Simülasyon Kullanımı”. Düzce Üniversitesi Sağlık Bilimleri Enstitüsü Dergisi, 4 (2), 25-29.

7. Aebersold, M. and Tschannen, D. (2013). "Simulation in Nursing Practice: The Impact on Patient Care". The Online Journal of Issues in Nursing, 18 (2), 6-6.

8. Alanazi, A.A, and Nicholson, N. (2017). "The Use of Simulation Training to Improve Knowledge, Skills, and Confidence Among Healthcare Students: A Systematic Review". The Internet Journal of Allied Health Sciences and Practice, 15 (3), 1-24

9. Aebersold, M. (2018). "Simulation-Based Learning: No Longer a Novelty in Undergraduate Education". The Online Journal of Issues in Nursing. 23 (2),1-1.

10. Robertson, B, Kaplan, B, Atallah, H, Higgins, M, Lewitt, M.I. and Ander, D.S. (2010). "The Use Of Simulation and A Modified Team Stepps Curriculum For Medical and Nursing Student Team Training”. The Journal of the Society for Simulation in Healthcare, 5 (6), 332-337.

11. Altıok, Ö. ve Üstün B. (2013). "Hemşirelik Öğrencilerinin Stres Kaynakları". Kuram ve Uygulamada Eğitim Bilimleri, 13 (2),747-766.

12. Gore, T, Hunt, C.W, Parker, F. and Raines, K.H. (2011). "The Effects of Simulated Clinical Experiences on Anxiety: Nursing Students' Perspectives". Clinical Simulation in Nursing, 7 (5), 175-180.

13. Mıdık, Ö. ve Kartal M. (2010). "Simülasyona Dayalı Tıp Eğitimi”. Marmara Medical Journal, 23 (3), 389-399.

14. Breitkreuz, K.R, Dougal, R.L. and Wright, M.C. (2016) "How Do Simulated Error Experiences Impact Attitudes Related to Error Prevention?" Simul Healthc, 11 (5), 323-333.

15. Yıldırım, A. ve Şimşek, H. (2006). Sosyal Bilimlerde Nitel Araştırma Yöntemleri. Ankara: Seçkin Yayıncılık.

16. Smith, J. and Osborn M. (2003). Interpretative Phenomenological Analysis. In: Editör J. SMITH (Ed.) Qualitative Psychology: a Practical Guide to Research Methods (pp.51-80). London: Sage Publications Ltd.

17. World Health Organization. (2018). "Simülation In Nursing and Midwifery Education". Available from:

18. http://Www.Euro.Who.Int/_Data/Assets/Pdf_File/0011/ 383807/Snme-Report-Eng.Pdf?Ua=1 (Cited 2019 January 20).

19. Hardavella, G, Aamli-Gaagnat, A, Saad, N, Rousalova, I. and Sreter, K.B. (2017). "How to Give and Receive Feedback Effectively". Breathe, 13, 327-333.

20. Behavioral Intervention Guide (2003). "Addressing Student Behavior: A Positive Approach". Available from:

https://www.vtnea.org/uploads/files/Behavior\%20Interve ntion\%20Guide-9.13.pdf (Cited 2019 March 3)

21. Günüșen, N.P. ve Üstün, B. (2012). "Hemșirelik Öğrencilerinin Klinik Eğitimde Verilen Geribildirime Yönelik Görüșleri”. Anadolu Hemşirelik ve Sağlık Bilimleri Dergisi, 15 (3), 197-204.
22. Arabac1, L.B, Korhan, E.A, Tokem, Y. ve Torun, R. (2014). "Hemşirelik Birinci Sınıf Öğrencilerinin İlk Klinik Deneyim Öncesi-Sırası ve Sonrası Anksiyete ve Stres Düzeyleri ve Etkileyen Faktörler”. Hacettepe Üniversitesi Hemşirelik Fakültesi Dergisi, 1-16.

23. Mcrae, M.E, Chan, A, Hulett, R, Lee, A.J. and Coleman, B. (2017). "The Effectiveness of and Satisfaction with High-Fidelity Simulation to Teach Cardiac Surgical Resuscitation Skills to Nurses". Intensive and Critical Care Nursing, 40, 64-69. 